\title{
Darwinian Approach and Mutations: Bjarke Ingels (BIG) and Analysis of His Stepped Pixels Buildings
}

\author{
Ayșenur Dağ Gürcan ${ }^{1} \odot$, H. Ercan Gürcan ${ }^{2} \odot$ \\ ${ }^{1}$ Lecturer, Faculty of Fine Arts and Design, KTO Karatay University, Konya, Turkey. (Principal contact for editorial \\ correspondence), Email: aysenur.dag@karatay.edu.tr \\ ${ }^{2}$ Faculty of Architecture and Design, Konya Technical University, Konya, Turkey. Email: mim.ercan.gurcan@gmail.com
}

\begin{abstract} Purpose

Ingels, who was influenced by Darwin, designs new mutants by developing prototypes. This study, it is aimed to scrutinize the public space alternatives proposed for the 21st-century city through the comparative analysis of the stepped pixelated buildings, one of the mutants of the architect. It has been how much questioned the stages, which offer a public space proposal, in the stepped pixelated buildings allow urban dialogue.

Design/Methodology/Approach

While Ingels' design philosophy constitutes the conceptual approach of the study, this study is prepared by using the architect's discourse, interviews, videos, digital texts, and literature studies. In this context, the repetitive examples that the architect defines as mutation and adaptation are classified. The stepped pixels in this classification are the main subject of this study. Ingels' pixelated buildings; Suitable human scale, the language of mass and form, relationship between human and space, the suggestion of space for experience, public space concept, dialogue spaces were discussed based on architect's approach.

Findings

Ingels went in the way of dividing the object through pixels when designing macro-scale structures. Thus, he made the big picture more understandable and perceptible. He tried to achieve the human scale with the gradual pixels rising from the ground level. In this way, Ingels' pixels buildings have transformed themselves into an experiential part of urban.

Research Limitations/Implications

These parameters were evaluated under four dwelling buildings of the stepped pixel in the case study (Lego Tower, Mountain Dwellings, King Street West, 79 \& Park).

\section{Social/Practical Implications}

At this research, it is foreseen that the new living space suggestions consisting of stepped pixels designed by Ingels will undergo different mutations and come up with new urban alternatives in the future.

\section{Originality/Value}

Pixelated dwellings, one of the mutations of Ingels, who constantly draws attention to the problem of not integrating the buildings into the city in today's architecture, have been analysed and evaluated in the context of urban alliterations. In this way, research, a first in its field is important in terms of opening to discuss the alternative urban living spaces proposed by the architect for 21st-century architecture in the contemporary architectural environment.
\end{abstract}

Keywords: Bjarke Ingels (BIG), evolution, mutation, residential buildings, stepped pixels 


\section{INTRODUCTION}

The 21st century, thanks to technology, has not only allowed striking innovations in the field of architecture as in many other areas of the world but has also architecture has become distinct from its usual order for thousands of years. Today's architecture has turned into an experimental production laboratory where every architect experiences his own space. New approaches, suggestions, and manifestos about contemporary architecture and its problems have been put forward. One of these architects, Bjarke Ingels (BIG), advocates the necessity of new urban organizations and intends to provide innovative flexible urban vacancies.

By 1975, it can be accepted that architecture is the first and foremost production of not only constructed objects but also experiences and concepts (Hays, 2015, 120-121). As a result of the fast-developing techniques and technologies, architects who approach more conceptually than in context in the 1980s and afterward started to attract attention. The background of this tendency has been lying behind the economic power reconstructed by modernization and globalization in the neo-liberal era. As a result, the concept project stage of contemporary architecture has been changing from micro-scale to macro-scale as proof of the infinity of human imagination (Sağdıç, 2016, 182-183, 186).

Defining his designs between micro and macro scales, Ingels believes that architecture will lose its importance and the city will gradually gain importance in five years, in response to his approach focused on progress/process and development/growth (Kayım, 2010). At this point, the philosophical approach, discourse, and attitude of Ingels, which constructs life-oriented spaces, which criteria to provide a better urban environment in the design process, gain importance.

In Tschumi and Cheng's words $(2003,91)$, in today's global world, the architect is no longer just a person who deals with building art but also has a complicated definition of designing a website, linking relationships, managing information, managing and organizing affairs. Having this definition, Bjarke Ingels is seen as a new representative of Postmodern theory (Lægring, 2017, 334), and his architectural attitude in context is criticized (Yang $\mathrm{Di}, 2019$, 71-72). Ingels ironically reactivates postmodernist communication strategies (painting, narrative, symbolism).

Ingles was influenced by Deleuze and Nietzsche, whom he discovered during his student years in Barcelona. In his designs, he exhibits ironic and metaphoric attitudes like Nietzsche. BIG architecture, which carries a high iconography and irony with storytelling using diagrams, drawings, and comics, has a more pragmatist perspective (Pastor, 2012, 15). In his approach to design, he has used irony extensively starting from the design dictionary which includes the concepts of 'accidents and misunderstandings', 'random opportunities', 'karma', 'surprise', 'luck', and 'unexpected' (Balık, 2014, 17). 
Darwinian Approach and Mutations: Bjarke Ingels (BIG) and Analysis of His Stepped Pixels Buildings

While irony, which was a postmodern tool, was closely related to the works of Venturi and Scott Brown, the recall and reinterpretation of postmodern features in contemporary architecture have re-emerged especially in BIG's works (Balık \& Allmer, 2015A, 189). However, unlike the Venturian point of view, he does not refer to the history of architecture in his practices but instead includes contemporary celebrities, logos, and landscapes concerning the subject (Lægring, 2017, 333). The silhouette of the Swedish Princess who referred to Andy Warhol on the façade of the 'Arlanda Hotel' designed for Stockholm Airport and the view of Everest, which forms the façade of the car park floor of 'Mountain Dwelling', are ironic postmodern references.

According to Balık and Almer (2015A, 193), BIG's tendency to create 'a kind of hybrid' by combining historical references was interpreted as an ironic approach. These hybrid approaches, which are based on historical discourses are based on Mies Van der Rohe's 'Less is More', Venturi's 'Less is Bore' and Barrack Obama's 'Yes We Can' slogan ironically have been transformed by Bjarke Ingels into 'Yes is More' manifesto. Bjarke Ingels' discourse on 'Yes is More' is a summary of his pragmatist perspective. His attitude is an understanding of architecture that brings together contradictions and discrepancies. According to him, social conflicts are the main components of architectural creation. Rather than looking at the conflicts of a project as a constraint, he defined it as finding a way to connect and integrate differences by linking conflicting parts together (Møller, 2013). In an interview, Bjarke Ingels explained the "yes" philosophy as follows:

"All BIG's ideas are based on the idea that we can have them all at once. The solution is not to choose between the two options, but to achieve a balance and ensure the satisfaction of both sides. ... Continuing a project by saying 'no' to everything is perceived as 'radicalism'. But perhaps we should realize the radical potential of saying 'yes' to everyone. We need to find a combination that seems impossible for everyone to achieve exactly what they want, not by meeting the minimum expectations." (Alpay, 2006).

Ingels was inspired by the Dutch architect Rem Koolhaas, who used the slogan ' ${ }^{* *} \mathrm{k}$ context' for pragmatism. This slogan was born in opposition to previous architectural philosophies and coexisted with a subtext that ignored the context. Ingels also ignores the context and wants to construct his context with experience. However, it also emphasizes proposing a positive, humorous, even hedonic, and utilitarian architectural form (Knudsen, 2016).

Ingels thinks that yes should be said instead of no and that it should be said for the society, not the individual. He says that architecture is not one-dimensional. He states that he advocates an architectural stance to listen to what the society says and wants to be (Ingels, 2011). In BIG's architecture, it is essential to design the physical environment that maximizes human life, not the production of the architectural object. 
This physical environment is designed on the experience of a walkabout around the space. That is why Ingels prefers videos rather than photographs, arguing that architecture can be understood through experienced spaces.

Ingels defined their projects at the point between 'master plan' and 'masterpiece'. Most of the projects, which are single structures, can be said to have been designed as a neighborhood when evaluated at the urban scale. Urban spaces are designed with an interactive combination of public, semi-private, and private spaces. This new urban proposal within Ingels' idea of pragmatic utopia can be interpreted as an attitude towards the precise boundaries between architectural work and urban design. According to Ingels, volumes have been designed with different uses for the last eighty years, and designs are often made to separating spaces. Many problems have arisen due to physical, social, and culturally unconnected volumes and lack of an urban environment design (Ingels, 2010, 11-12). Thinking that architects have a responsibility to adapt to the new urban conditions and circumstances that shaped them, Ingels proposes innovative, flexible urban spaces for cities in the buildings he designs. In doing so, he wants to design urban conditions by capturing 'architectural alchemy' as he puts it and to construct spaces to increase spontaneous public interactions (Url-1).

In this context, the starting point of this study is the question of how much the architect allows for the spaces of interaction and dialogue in the public, semi-private and private spaces proposed in his designs for the city. This question has been tried to be resolved through the analogy method within the scope of the case study. First of all, the theoretical framework of the study was formed through the design philosophy of the architect. There are architectural forms that the architect repeats himself and defines as adaptation and mutation under the philosophy of evolution. These forms are classified in the theoretical part of the study. The sampling area was created with the stepped pixels in this classification. The architect has six projects of stepped pixels. One of them is the museum, the other is the pavilion and the remaining four are residential complexes. The examples were evaluated based on the criteria of stepped pixels, the relationship between human and space, mass and form language, approaching human scale, the suggestion of space for experiencing, public space proposal, and spaces of dialogue. These criteria are analyzed through diagrams, plans, images, fiction, and real interaction spaces.

Lego Tower, Mountain House, King Street West, 79 \& Park projects, which offer a new habitat proposal, were evaluated based on the above parameters, and urban experience interaction areas were discussed. In this context, it has been determined that the cascaded pixelated structures, one of the mutations of Ingels, are examples that differ in themselves and are adapted and mutated according to the place. 
Darwinian Approach and Mutations: Bjarke Ingels (BIG) and Analysis of His Stepped Pixels Buildings

The responsibility of the architect to take urban inputs as a reference while creating his context and to develop solutions for the city is a new breath brought to 21-century architecture.

The 21st century, with the effect of rapidly developing technology and changing daily life, has made the history of architecture more diverse theoretically. In this context, it is no longer possible to talk about a movement or a common architectural thought and instead of this, the discourses of the architects defined a theoretical field. 21st-century architecture has turned into a changing paradigm even in the architect. At this point, this study is beyond monographic research, and it has been built based on an architect's design philosophy and tendencies. Thus, in the study, the tendency of the architect was evaluated based on his suggestions to the city and his discourses. The work is important to contribute to contemporary architecture on a specific subject (Figure 1).

Figure 1. Diagram of research process (Drawings by the Authors, 2020).

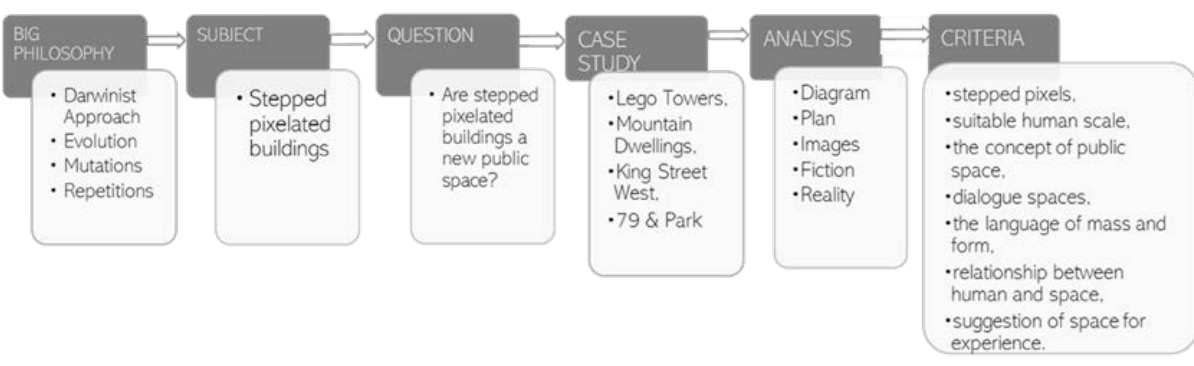

THEORETICAL FRAMEWORK: REPETITIONS AND MUTATIONS FROM THE DARWINIST PERSPECTIVE

Ingels was influenced by Darwin and argued that his tree of evolution might be a diagram of BIG's way of working. In every architectural process, a lot of ideas initially arise, but only a few of them continue. In the architectural selection process, we combine them, that is, we create a mutant (Ingels, 2009). This architectural evolutionary process can be interpreted by natural selection, the main mechanism of evolution. The most advantaged of each species survives more and transfers the positive genes to future generations. Thus, advantageous properties are increased in number, disadvantageous properties are gradually reduced. As a result of this elimination mechanism, the evolving species gain adaptation ability (Futuyma, 2005, 8). In BIG architecture, strong ideas put forward during the selection process are developed and continued. The powerful design idea is shaped in the process according to its location by gaining adaptation ability. The importance of this adaptation ability is evaluated from a Darwinist perspective.

Charles Darwin mentions the idea of subspecies besides the idea of a single species. This situation is evaluated in BIG architecture as follows. Every idea spoken at project design meetings has value. If this did not work in the context of the project, there may be an answer to a different question of another client from another culture in another time frame 
(Ingels, 2009). So, nothing is thrown away in the offices, the architecture office is home to biodiversity. This repetition mentality emerges concerning working in series and designing concepts, forms, and ornaments independently of the program and context (Lægring, 2017, 327). The problem of repetition has been discussed in critical articles on BIG, especially in the "Bjarke Ingels Group" issue of Clog magazine.

Ironically the repetition of shapes and concepts through slogans such as "repetitive transport operations" or "fit pyramid shape in any context" has also been criticized by Ho, $(2012,55)$ and Buinno $(2012,37)$, (Balık and Allmer, 2015A, 196-7).

Ingels' ability to adapt his designs can be explained by the capability to adapt to the environment in which the form takes place. For example, when a proposed building in Sweden was not implemented, it was made as a proposal in China with little change (Ingels, 2010, 26). It was tried to create context and define the public sphere by giving references to the local characteristics of China. At this point, Foster's (2011, x) effort to give a local appearance to the global one, which he said against the global style, can be said for the architectural attitude of Ingels.

In BIG architecture, there is a specific representation for each project. Each project has a monographic history and natural selection for all. The basis of the story lies in how it evolved from the idea it came from. BIG defines diagrams in the project process with the desire to show traffic flow, climate change, location, settlements, contextual and historical references of a place and dynamic results (Pastor, 2012). Ingels explained the essence of the diagrams in his work by the Danish philosopher Søren Kierkegaard's words 'life is moving forward but being understood backward'. The evolutionary tree in the design process swallow ups every result and infinite possibilities, that is to say, by the simple expression, the diagram is obtained by going back to the result (Ingels, 2011).

According to Ingels, as the renewals and repetitions of a project increase, it will be richer, and more situations will be tested. Therefore, he believes that unsuccessful attempts in the design process will be appropriate. The rise of a series of miniature plastic mountains lived by tiny plastic people in the Copenhagen studio is a concrete demonstration of this approach (Davidson, 2017).

BIG has become a kind of urban laboratory that develops ideas by producing species that develop prototypes. For in support of BIG's tendency to multiply in this direction, Ingels points to Le Corbusier's 'Vers Une Architecture (1923)', emphasizing the production of typologies. Confirming its sameness through Le Corbusier, Ingels (2012, 106) believes that different architects can develop and use the typology produced instead of starting from scratch (Balık and Allmer, 2015A, 196). 
Darwinian Approach and Mutations: Bjarke Ingels (BIG) and Analysis of His Stepped Pixels Buildings

Table 1. BIG's repetitions and mutations (The images in the table are taken from the official website of BIG. [https://big.dk/\#projects])

\begin{tabular}{|c|c|}
\hline Mutations & Examples \\
\hline $\begin{array}{l}\text { Diagonals } \\
\text { and } \\
\text { mountain } \\
\text { metaphor }\end{array}$ & $\begin{array}{l}\text { A } \\
\begin{array}{l}\text { Via 57 West, } \\
\text { New York, 2015. }\end{array} \text { Amsterdam, Under construction. Malmö, Idea, 2008. }\end{array}$ \\
\hline $\begin{array}{l}\text { stepped } \\
\text { pixels }\end{array}$ & 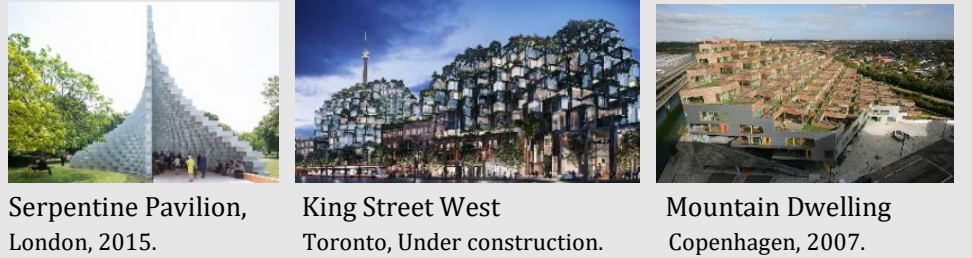 \\
\hline $\begin{array}{l}\text { shifting of } \\
\text { the plaques }\end{array}$ & $\begin{array}{lll}\text { Grove at Grand Bay } & \text { Suitsupply Headquarters } & \text { Wilson Secondary School } \\
\text { Miami, 2016. } & \text { Amsterdam, In progress, 2017. } & \text { Arlington, 2019. }\end{array}$ \\
\hline $\begin{array}{l}\text { breaking of } \\
\text { the form }\end{array}$ & $\begin{array}{llc}\text { Arctic Cultural Center } & \text { The Holy Road Athens } & \text { Tirpitz Museum } \\
\text { Hammerfest, Idea, 2005. } & \text { Athens, Idea, 2008. } & \text { Blåvand, 2017. }\end{array}$ \\
\hline $\begin{array}{l}\text { bending of } \\
\text { the mass }\end{array}$ & $\begin{array}{l}\text { Scala Tower Vancouver House } \quad \text { Walter Towers } \\
\text { Copenhagen, Idea, 2007.Under construction, 2012. Prague, Idea, 2007. Shanghai, Idea, 2005. }\end{array}$ \\
\hline $\begin{array}{l}\text { slit and holes } \\
\text { opening to } \\
\text { mass }\end{array}$ & $\begin{array}{l}\text { Singapore Tower Epiq Tower } \quad \text { MÉCA Cultural Center } \\
\text { Taiwan, Idea, 2009. Under construction, 2018. Quito, 2019. Bordeaux, 2019. }\end{array}$ \\
\hline $\begin{array}{l}\text { helical } \\
\text { ramps and } \\
\text { spiral } \\
\text { tendencies }\end{array}$ & 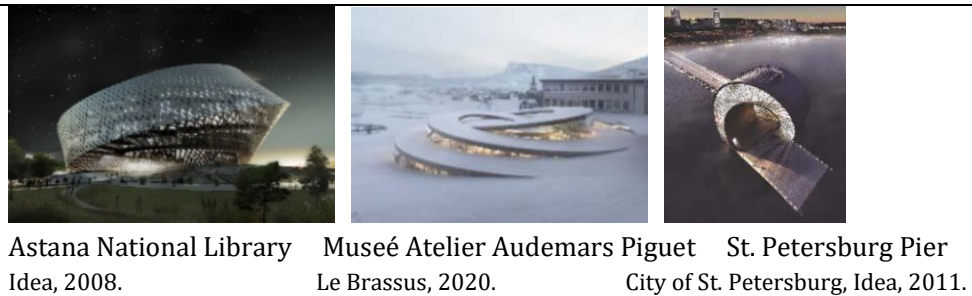 \\
\hline
\end{tabular}

Apart from his projects that are shaped according to the situation, it is clear from the above statements that Ingels was referred to repetitions, as read from his expressions and images. Keeping the numerous changed mass in the design process against the possibility of later use 
may be the reason why the architect does not abandon some passion and tendencies. Recurring forms in BIG's architecture have shown themselves as stepped pixels, diagonals designed with mountain metaphor, shifting of the plaques, breaking of the form, bending of the mass, slit and holes opening to mass, helical ramps and spiral tendencies (Table 1).

\section{RESEARCH METHOD: ANALYSIS OF STEPPED PIXELS BUILDINGS}

Today, our world is a giant ongoing urban laboratory, constantly conducting new experiments, evolving new life forms and inventing new spaces, tools and toys (Ingels, 2012A, 128).

One of Ingels' contributions to this laboratory is that he goes in search of alternative urban spaces using stepped pixels to transform legos into real architectural products.

According to Philippe Boudon $(2015,129)$, while architectural works of today have grown considerably, architecture has decreased paradoxically at this rate of growth, and the city itself has emerged as an object. At this point, Boudon which talks about the concept of scale emphasized the view that problems were overcome with the tendency to divide the real object Strauss (2000, 34-35) said about the virtue of reduction. With the downscaling of the scale, the whole object does not become as formidable as before. The quantitative downsizing of the object allows for the simplification of perception qualitatively. At this point, carrying Boudon's worry Ingels may have used the way of dividing the form into sections over pixels, while designing macro-scale structures. Another reason why Ingels uses pixel editing in his designs may be due to his passion for Legos.

The passion for Lego has been undeniably influential in the architecture of Ingels, who enjoys painting and playing with Legos as a child. Saying that he learned how to overcome clear hardness in a Lego system as a child, Ingels found how to turn restrictions into freedom by maximizing creativity with limited resources (Davidson, 2017, 60-61). In BIG architecture, Lego's are the pieces that the architect frequently refers to in his designs emulating the mountain metaphor. Although Lego's are built-in pixels in most Ingels projects, the Lego House project differs from other examples by moving a standard Lego brick to an architectural scale. Designed as an urban area as well as an experience center, Lego House consists of 21 Lego spaces located on different elevations around a central closed square. The staging of these Lego's indoors and outdoors allows users to experience and dialogue spaces. Two of the building's Lego terraces turn into a public amphitheatre consisting of pixelated steps, allowing for performance watching and sitting (Figure 2). 
Figure 2. Lego House and pixels (Url-3)

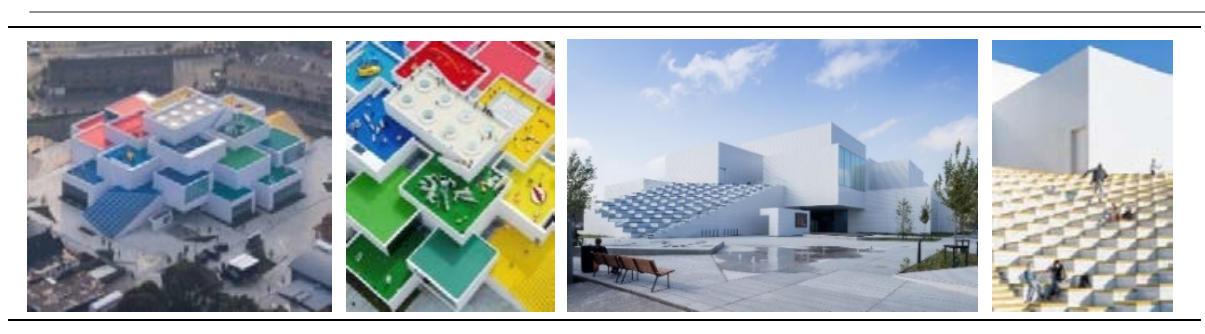

Another example of Ingels with stepped pixels is the Serpentine Pavilion. The building, which consists of 1800 fiberglass blocks, refers to the top of a mountain with the blocks placed on top of each other and rising $14 \mathrm{~m}$ (Url-2). This transparent mass; When connecting indoor and outdoor spaces, block steps have become an urban object that allows sitting, resting, chatting, and watching actions. This structure is an exhibition type of the small-scale version of Ingels' pixelated structures. The main idea focused on experience and dialogue is also seen in pixelated residential complexes of Ingels. The idea of suburban, which is the architect's expression, which aims to combine suburban life with urban space, manifests itself in stepped pixelated living spaces, from BIG mutations.

At this point in the study, the socialization areas of Ingels' topography, realized with his pixel or Lego attitude, were evaluated over seven criteria consisting of stepped pixels, suitable human scale, the concept of public space, dialogue spaces, the language of mass and form, relationship between human and space, and suggestion of space for experience. Urban experiences spaces were discussed through the Lego Tower, Mountain House, King Street West, 79 \& Park projects that offer a new habitat proposal. Supported by the idea of Suburban, these residential complexes were analyzed in this section by tabulating on diagrams, plans, pictures, fictionalized, and real spaces. However, since the Lego Tower in the examples is an idea, and the King Street West project is under construction, the plans and real space visuals of these projects could not be reached.

\section{Lego Tower, Copenhagen, 2006, Idea;}

The building form was designed by shaping the elastic module's main idea defined by the regions with varying density. Then, the soft topography of urban gathering was adjusted by rough pixelation of the peaks and valleys of the landscape. One of the proposed urban alternatives is the amphitheatre. On the ground level of the building, sales units and parking areas are proposed. Terraces belonging to residences and offices are designed in rising steps. And it was aimed to create semi-private privacy areas by preventing access to these areas with the public spaces (Ingels, 2010, 113) (Table 2).

Here, the architect proposed an urban hill by configuring each square separated by pixels on flat ground at a different height. These pixels were presented in the 'Yes is More' exhibition with a 1/500 scale Lego model consisting of a square of the Lego. Ingels desired the urban hill 
designed for Copenhagen, which has a flat topography, to give a new breath to the city's silhouette. He aimed to create spaces for urban dialogue in stages and designed these dialogues in his book 'Yes is More'. It has been stated with a pragmatic attitude that everyone is satisfied with this urban scenario.

Another issue that is considered in this study is the criticism of going beyond the human scale brought to high-rise buildings. The design approach following the human scale was considered within the scope of this project concept. In this case, the design suitable for the human scale is provided with consistent modules that continue throughout the building cover.

As in Pallasmaa's $(2016,83)$ testimony 'When the body finds its resonance in the place, we feel pleasure and security', for this reason, an effort to make a high-rise building suitable for human scale can be seen here. In fact, this effort was supported using people in models. Thus, it was expected to allow sincere dialogue and urban alliterations. However, the fact that this project remains an idea and has not been implemented yet does not allow us to experience the desired dialogue spaces in the fiction of urban steps.

Table 2. Lego Tower and stepped pixels (The images in the table are taken from the official website of BIG [Url-4]).

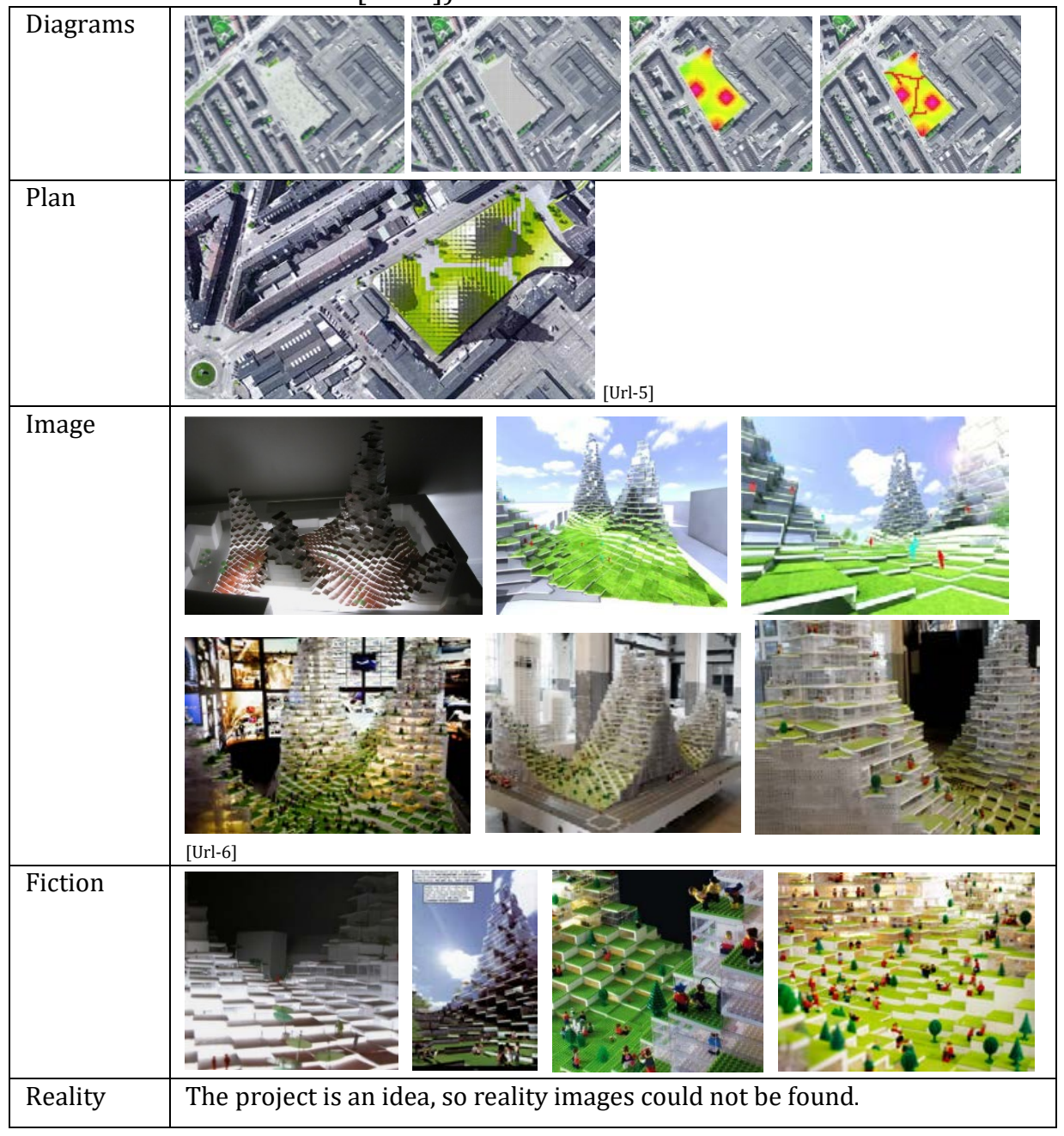


Darwinian Approach and Mutations: Bjarke Ingels (BIG) and Analysis of His Stepped Pixels Buildings

\section{Mountain Dwellings, Copenhagen, 2007:}

The project, built next to the VM house previously built by BIG, located in Ørestad, the new urban development area of Copenhagen, was produced as a solution to a parking lot and housing demand. In the building designed on flat ground again, the architect, in his own words, if you want a beautiful view looking south in Copenhagen, you simply do this yourself (Ingels, 2009) defined his artificial mountain.

Keeping the city and suburban life together is the basic concept of the project. Ingels described this structure in an interview as follows. "What was interesting in Mountain Dwellings was the merging of a large residential building with the parking garage.

The fact that the parking lot was placed under the housing units made the apartments a flat with a garden. If you look at the project, it seems as if you cut a piece from a very huge suburban area and placed it in the parking garage. If you enlarge the parking area we take as the ground, you get more suburbs. With this approach, the suburban lifestyle combines with the urban lifestyle represented by the parking lot." (Alpay, 2006). Describing the design approach with this explanation, Ingels proposes a gradual vertical suburb.

While each pixel represents a residential unit, terraces serve as a garden. These pixelated terraces facing south have risen from the ground level and when viewed from this point, the building has been brought closer to the human scale (Table 3). The parking garage, gymnasium, and commercial units are designed by evaluating the space under the graded residential units. Reference was made to the mountain metaphor on the stepless surfaces with these functions, and the image of Mount Everest was pixelated on the perforated metal coating and displayed on the facade. In the project, which presents the 'imitation' experience of living in a mountain, the architects have prepared a project that includes not only the wrapped image of a mountain applied to the facade of the building but also other 'mountain' experiences such as climbing (Balık \& Allmer, 2015B, 31-33).

In Mountain Houses, the experience idea of the architect was tried to be kept alive with the metaphor of the 'mountain', but a common open area where the users could be together was not described. While the gym, car park, and commercial spaces located on the ground level are open to everyone, the pixels containing the residences do not have any concerns about creating an urban common area. Each of the levels is private terraces belonging to the users. At this point, it is noteworthy that the terraces on the same floor are connected by the door. Here, the architect touched on neighborhood relationships and defined semi-private open spaces for the dialogue between neighbors by a transitive terrace pattern. At this point, the concepts of the architect have been mutated, but the passion to rise by pixelation and the desire to create experience has not changed. 
Table 3. Mountain Dwelling and stepped pixels (The images in the table are taken from the official website of BIG [Url-7], [Url-8] and google maps [Url-9]).

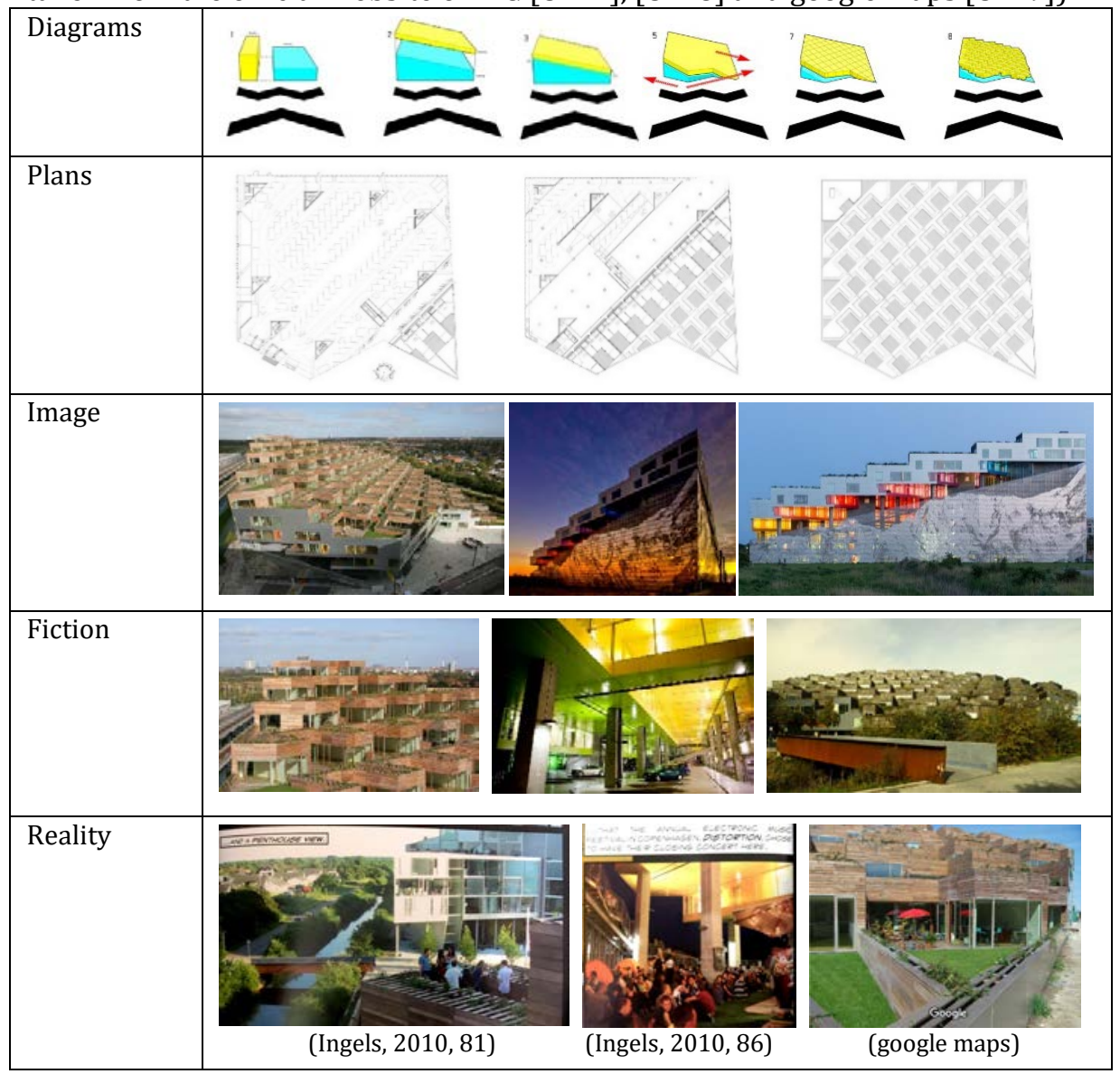

King Street West, Toronto, 2016, in progress:

King Street West is in the transition area between Toronto's high and low-rise buildings. Ingels' inspiration for this project was Moshe Safdie's Montreal Habitat (1967) project and it was aimed to define an innovative living space that refers to this project. The architect used the idea of the stage and the courtyard together. These stages, which surround the historical buildings in the study area, are handled in pixels. Each pixel rotated 45 degrees to the street for increased access to daylight and open-air and it was adjusted to the size of a room. The wavy design obtained by the gradual placement of the pixels allowed the light to reach the building and the courtyard all year round.

Stages are designed in two ways as private terraces and shared terraces. Shared terraces are considered as urban agriculture potential and gathering places. However, in this project, it is not possible to say that terraces are a real public space since the steps do not go down to the ground. The courtyard idea of the architect describes public space. There are no steps in the courtyard, but the different heights of the pixels in the mass are felt here. As understood from the diagrams, the courtyard also acts as a nodal point connecting the different neighborhoods of the city (Table 4). 
Darwinian Approach and Mutations: Bjarke Ingels (BIG) and Analysis of His Stepped Pixels Buildings

The emptied pixels of the levels that surround the courtyard invite the people to the courtyard, and at the same time, it is designed as a living passage place with cafes, boutiques, seating units, and green areas in the courtyard. However, since the project is under construction, there is not mentioned real urban experience yet.

The mutation of Ingels here is that the stepped pixels are formed around a courtyard. The public space proposal that differs here is for the courtyard located under and in the center of the graded pixelated units rather than the stepped terraces, which are private and semi-private spaces.

Table 4. King Street West and stepped pixels (The images in the table are taken from the official website of BIG [Url-10] and [Url-11, 12, 13, 14])

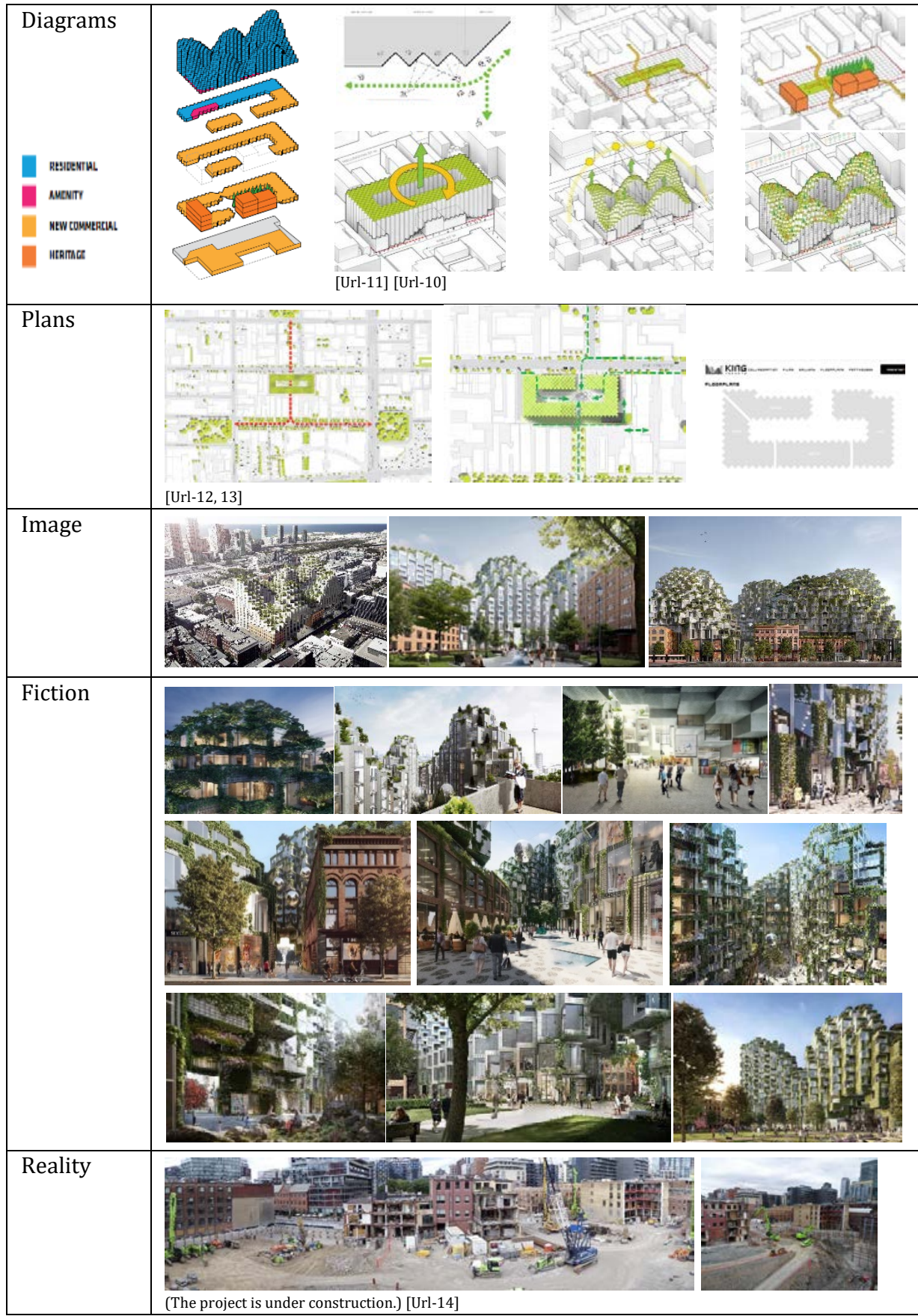




\section{9 \& Park, Stockholm, 2018:}

The mass housing project in Stockholm is one of the completed projects of BIG. Continuing the pixelated building custom, Ingels has adopted an environmentally sensitive design approach. The mass directed towards Gardet Park gradually descended with a pixel tongue scaled according to human size. The southwestern facade of the building facing the Gardet park is the lowest point of the pixelated building. Pixelated terraces, which are a passage between nature and the building, turn into a public platform. Wooden covered pixels, consisting of 3.6 x 3.6 modules, organized around a green courtyard in the center, are a new representation of BIG's artificial mountains (Table 5).

In the words of the architect, "This manipulation not only allows for a more organic expression, perfectly reflecting the surrounding landscape, but also provides a way to accomplish the building topography in a controlled and inexpensive way through the use of prefabricated units of standardized sizes"(Url-15).With the various commercial areas on the ground floor and a platform open to the public at the southwestern point of the building, the usual closed housing form has been turned into an urban space.

Table 5. 79 \& Park and stepped pixels (The images in the table are taken from the official website of BIG [Url-16])

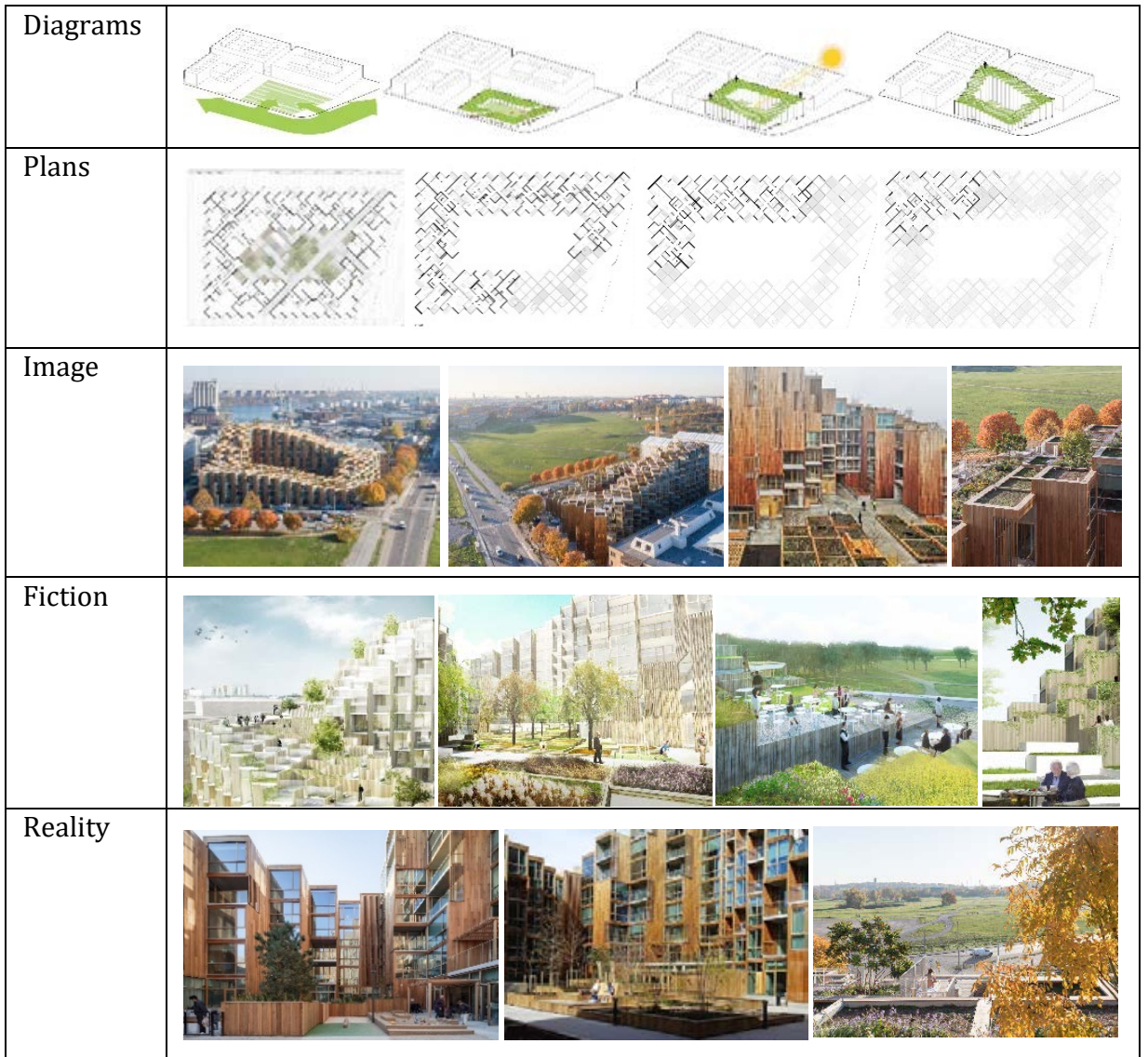

BIG proposed the integration of public and private spaces that allow new experiences in the city with a pragmatist perspective. Steps from 7 
Darwinian Approach and Mutations: Bjarke Ingels (BIG) and Analysis of His Stepped Pixels Buildings

to 35 meters form the boundaries between public, semi-private, and private areas. The courtyard in the center of the graded pixels defines a semi-public space. The courtyard offers activity areas with different textures and elevations placed in a grid system with pixels of 3.6 x 3.6. The pixels in the courtyard offer various experience areas such as circulation, green area, small activity pockets for activities, dog park, bicycle park, and activity areas (such as sandbox) reserved for preschool education for residents and visitors.

All residences have access to private and shared terraces. Although this structure of Ingels showed similarity with the fiction of the courtyards and pixels in the King Street West project, it was mutated. The mutation here is due to the location of the building, the courtyard closes a little further and the gradual pixels are special, as well as functioning as shared terraces.

\section{EVALUATION}

In the study, while living areas of stepped pixels, one of BIG's mutations, have been criticized, the status of being an experiential part of the city has been questioned. Since Lego Towers remains an idea project, the real urban experience cannot be mentioned. But it is the first example of stepped pixels in BIG's architecture. It was designed in response to the question of how to reduce a tower to the human scale. Urban interaction areas have been proposed on the terraces of different grades that rise from the ground level and provide the experience of climbing a mountain. In these multifunctional towers with urban experience, it is seen that thousands of pixels at different levels starting from the ground level define the degree of privacy at the same time.

In Mountain Dwelling, pixels have been brought together with the idea of a vertical suburb. Experience terraces in graded pixels in Lego Towers have been replaced by private terraces of the residential units. There is no public space proposal for the pixels here. Pixels serve the purposes of landscape orientation, terrace, and mountain metaphor.

The King Street West project is an example of the pixel mutation supported by the idea of a courtyard. While the stepped pixels are designed as private and shared terraces, the publicly recommended space has been the courtyard. Although a public area cannot be defined for the pixels that do not go down to the courtyard level, the integration of the public courtyard and the pixels surrounding it strengthened the urban dynamics of the project. The location of this building is an important place in the city center made it possible for the building to function as a nodal point. With the idea of being a nodal point, openings were created in the courtyard and pixels, and a closed-form concept was rejected. Therefore, in this example, it is predicted that the fiction of a courtyard with a pixel will be more integrated into the city. Since the building is currently under construction, predictions have been made through diagrams, plans, visuals, and fiction for urban experience and reality. 
Another example with courtyards and pixels is the $79 \&$ Park project. In this building, Ingels turns the pixelated terraces into a public platform towards the park. As in Lego Towers, rising gradually pixels form the boundaries between public, semi-private, and private spaces. The courtyard here is designed to be less passive due to its location compared to King Street West, which will be located at an important point in the city center, while the terraces of the building offer more shared areas. The idea of pixelating the mass that the architect repeats itself has mutated according to the changing time and the proposed location, as in the examples critical in the study. In the early examples (Lego Towers and Mountain Dwelling), the fiction of pixel was used alone, while in the recent examples (King Street West and 79 \& Park), the courtyard was included also in this fiction (Table 6).

Table 6. Evaluation of criteria based on examples

\begin{tabular}{|c|c|c|c|c|}
\hline$\rightarrow$ Examples & \multirow{2}{*}{$\begin{array}{ll}\text { Lego } & \text { Tower, } \\
\text { (Idea) } & \end{array}$} & \multirow[t]{2}{*}{$\begin{array}{l}\text { Mountain } \\
\text { Dwelling }\end{array}$} & \multirow{2}{*}{$\begin{array}{l}\text { King Street } \\
\text { West, } \\
\text { (Process) }\end{array}$} & \multirow[t]{2}{*}{79 \& Park } \\
\hline$\downarrow$ Criteria & & & & \\
\hline $\begin{array}{l}\text { Stepped } \\
\text { Pixels }\end{array}$ & $\begin{array}{l}\text { Public, } \\
\text { Semi-private, } \\
\text { Private }\end{array}$ & Private & $\begin{array}{l}\text { Semi-private, } \\
\text { Private }\end{array}$ & $\begin{array}{l}\text { Public, } \\
\text { Semi-private, } \\
\text { Private }\end{array}$ \\
\hline $\begin{array}{l}\text { Suitable } \\
\text { Human Scale }\end{array}$ & $\begin{array}{ll}\text { Fiction: } & \checkmark \\
\text { Reality: } & -\end{array}$ & $\begin{array}{ll}\text { Fiction: } & \checkmark \\
\text { Reality: } & \checkmark\end{array}$ & $\begin{array}{ll}\text { Fiction: } & \checkmark \\
\text { Reality: } & -\end{array}$ & $\begin{array}{ll}\text { Fiction: } & \checkmark \\
\text { Reality: } & \checkmark\end{array}$ \\
\hline $\begin{array}{l}\text { Concept of } \\
\text { Public Space }\end{array}$ & $\checkmark /$ Pixel & $x$ & $\checkmark /$ Courtyard & $\checkmark /$ Pixel \\
\hline $\begin{array}{l}\text { Dialogues } \\
\text { spaces }\end{array}$ & $\begin{array}{ll}\text { Fiction: } & \checkmark \\
\text { Reality: } & -\end{array}$ & $\begin{array}{ll}\text { Fiction: } & \checkmark \\
\text { Reality: } & \checkmark\end{array}$ & $\begin{array}{ll}\text { Fiction: } & \checkmark \\
\text { Reality: } & -\end{array}$ & $\begin{array}{ll}\text { Fiction: } & \checkmark \\
\text { Reality: } & \checkmark\end{array}$ \\
\hline $\begin{array}{l}\text { Language of } \\
\text { Form and } \\
\text { Mass }\end{array}$ & $\begin{array}{l}\text { Hills, Towers, } \\
\text { Lego } \\
\text { Landscape: } \\
\text { Walley and } \\
\text { Peaks }\end{array}$ & $\begin{array}{l}\text { Mountain, } \\
\text { Scenery, } \\
\text { Vertical Suburb }\end{array}$ & $\begin{array}{l}\text { Habitat 67, } \\
\text { Stepped } \\
\text { Pixels and } \\
\text { Courtyard, } \\
\text { Surround the } \\
\text { Historical } \\
\text { Buildings, } \\
\text { Nodal Point } \\
\end{array}$ & $\begin{array}{l}\text { Directed } \\
\text { towards Park, } \\
\text { Prefabrication, } \\
\text { Stepped Pixels } \\
\text { and Courtyard, }\end{array}$ \\
\hline $\begin{array}{l}\text { Relationship } \\
\text { between } \\
\text { Human and } \\
\text { Space }\end{array}$ & $\begin{array}{l}\text { House, Office, } \\
\text { Commercial, } \\
\text { Auto park, } \\
\text { Amphitheatre }\end{array}$ & $\begin{array}{l}\text { House, } \\
\text { Commercial } \\
\text { (ground floor) } \\
\text { Auto park, } \\
\text { Sport Hall }\end{array}$ & $\begin{array}{l}\text { House, } \\
\text { Commercial, } \\
\text { Courtyard, } \\
\text { Café, } \\
\text { Greenspace }\end{array}$ & $\begin{array}{l}\text { House, } \\
\text { Courtyard, } \\
\text { Public } \\
\text { platform, } \\
\text { Greenspace, } \\
\text { Commercial }\end{array}$ \\
\hline $\begin{array}{l}\text { Suggestion of } \\
\text { Space for } \\
\text { Experience }\end{array}$ & $\begin{array}{l}\text { Amphitheatre } \\
\text { Public, Semi- } \\
\text { private and } \\
\text { Private } \\
\text { Terraces, } \\
\text { Experience of } \\
\text { Climbing to } \\
\text { Mountain }\end{array}$ & $\begin{array}{l}\text { Suburban } \\
\text { apartment and } \\
\text { house with a } \\
\text { garden) } \\
\text { Sequences and } \\
\text { Transitional } \\
\text { Private } \\
\text { Terraces, } \\
\text { Experience of } \\
\text { Entered into } \\
\text { the Mountain }\end{array}$ & $\begin{array}{l}\text { Public } \\
\text { courtyard, } \\
\text { Semi-private } \\
\text { and Private } \\
\text { Terraces: } \\
\text { Urban } \\
\text { Agricultural } \\
\text { Potential, } \\
\text { Meeting } \\
\text { Places }\end{array}$ & $\begin{array}{l}\text { Semi-private } \\
\text { courtyard, } \\
\text { Relation to } \\
\text { park, } \\
\text { Public } \\
\text { platforms, } \\
\text { Semi-private } \\
\text { and Private } \\
\text { Terraces }\end{array}$ \\
\hline
\end{tabular}

At this point, it is expected that new living space proposals consisting of stepped pixels, which Ingels frequently refers to, will come together 
Darwinian Approach and Mutations: Bjarke Ingels (BIG) and Analysis of His Stepped Pixels Buildings

with different spaces and undergo different mutations, as in the courtyard example, and come up with new urban alternatives in the future.

\section{CONCLUSION}

Ingels has gone on the way to divide the object by pixels while he is designing macro-scale buildings that keep up with the philosophy of his age, create his context, and organize his own space. Advocating that the focus should be on the big picture, Ingels tried to reduce by pixelating the main form to make the big picture better understandable and perceptible. He aimed to approach the human scale with the gradual pixels that started from the ground level. Thus, the structure transformed itself into an experiential part of an urbanism without intimidating the user. Ingels also tried to define the units of the building with the pixelation method. While pixels constitute a module for living spaces, they also define terraces. In this context, stepped pixels enabled open and closed living spaces at different levels while defining the boundaries of private, semi-private, and public spaces. The pixelation approach, which offers the opportunity to limit and define the space in the context of plan and height, emerges as a new quest in 21st-century architecture. It is predicted that Ingels, which has only four pixelated dwellings on the macro scale, will continue this mutation with different alliterations in the future.

In this context, Ingels' urban design-oriented approach is an architectural approach that seeks new scenarios for 21st-century architecture, suggests urban experiences and dialogue spaces, constructs positive scenarios, and questions the demands of the age. In response to the architects who criticized BIG, Ingels stated that they tried to observe how life develops instead of personal biased ideas about how the world should be, and at this point, they aim to realize lifeoriented designs rather than architectural purposes.

Ingels whose star is shining in the Globalizing World maybe succeeded in becoming a starchitect in the 21st-century environment, by making references to the popular culture and being in this culture, performing its own utopia with a utilitarian attitude. Bjarke Ingels, which creates its own context in the topography that it has created, has drawn a common portrait of 21st-century people and has an architectural attitude towards this portrait in a world whose borders have disappeared. Despite all the criticisms directed at him, to understand the society and architecture of today, it will be important to evaluate Ingels, his architectural approach, and the new proposals he presented to the city through different mutations. At this point, the study is expected to form a basis for future research at the intersection of urban and architecture.

\section{ACKNOWLEDGEMENTS}

The main plan of this study was shaped by the doctorate lecture taken by Ayşenur Dağ Gürcan in Gazi University Department of Architecture. 
For her contributions, I would like to thank Prof. Dr. Aysu Akalın who is the lecturer of the 'Form and Structure of Spatial Image: Perceptual Process Between Man and Space' course.

\section{CONFLICT OF INTEREST}

No conflict of interest was declared by the authors.

\section{FINANCIAL DISCLOSURE}

The authors declared that this study has received no financial support.

\section{ETHICS COMMITTEE APPROVAL}

Ethics committee approval was not required for this article.

\section{LEGAL PUBLIC/PRIVATE PERMISSIONS}

In this research, the necessary permissions were obtained from the relevant participants (individuals, institutions and organizations) during the survey, in-depth interview, focus group interview, observation or experiment.

\section{REFERENCES}

Alpay, Z. (2006, November 23). Mimarca Bir Meydan Okuma; Bjarke Ingels ile Söyleşi. [A Challenge by Architect; Interview with Bjarke Ingels]. https://v3.arkitera.com/soylesi_55_bjarke-ingels.html

Balik, D. (2014). Deciphering Ornament, Dissecting "Big": The Return of Ornament in Contemporary Architectural Theory and Practice. Doctoral dissertation, Dokuz Eylül University, Graduate School of Natural and Applied Sciences.

Balik, D., \& Allmer, A. (2015). This is not a mountain!: Simulation, imitation, and representation in the Mountain Dwellings project, Copenhagen. Architectural Research Quarterly, 19(1), 30-40. https://doi.org/10.1017/S1359135515000196

Biunno, J. (2011). Architects! Out of Ideas? In Clog: Bjarke Ingels Group (pp. 1-37). CLOG.

Boudon, P. (2015). Mimari Mekan Üzerine, Mimarlık Epistemolojisi Üzerine Deneme (Sur l'espace architectural). Janus.

Davidson, J. (2017, June). Designing Tomorrow. Smithsonian, 56-65. https://www.smithsonianmag.com/innovation/bjarke-ingels-makesimpossible-concrete-180963301/

Di, Y. (2019). Architects and Global Marketing - Buying and Selling in China. 2019 XJTLU International Conference: Architecture across Boundaries, KnE Social 6ciences, 66-75. https://doi.org/10.18502/kss.v3i27.5515

Foster, H. (2011). The Art-Architecture Complex. Verso.

Futuyma, D. J. (2005). Evolution. Sinauer Associates.

Hays, M. K. (2015). Mimarlığın Arzusu Geç Avangardı Okumak (Architecture's Desire: Reading the Late Avant-Garde). YEM. 
Darwinian Approach and Mutations: Bjarke Ingels (BIG) and Analysis of His Stepped Pixels Buildings

Ho, H. H. (2011). [Trans]planted / [Re]placed. In Clog: Bjarke Ingels Group (pp. 54-55). CLOG.

Ingels, B. (2011, October 7). CLOG: BIG Launch Interrogation of Bjarke Ingels. CLOG. http://www.clog-online.com/news/clog-big-storefronttranscript/

Ingels, B. (2010). Yes is More: An Archicomic on Architectural Evolution. Taschen.

Ingels, B. (2009, November 20). TEDxTalks. TEDxAmsterdam. [Video] https://www.youtube.com/watch?v=8fleg8Q2ZLU

Ingels, B. (2012). Public Participation Extreme. Perspecta, 45, 127-130. http://www.jstor.org/stable/24728122

Ingels, B. (2011). Responses. In Clog: Bjarke Ingels Group (pp. 102-111). CLOG.

Kayım, E. S. (2010, November 3). Dünya Mimarlık Festivali'ne Ingels ve Griffiths Dopingi [Ingels and Griffiths Doping to the World Architecture Festival]. Mimarizm Mimarlık ve Tasarım Yayın Platformu. https://www.mimarizm.com/haberler/dunya-mimarlik-festivali-neingels-ve-griffiths-dopingi_116789

Knudsen, L. E. D. (2016, August 22-26). Context-free pragmatism in Danish campus architecture [Paper presentation]. 2016 ECER Leading Education: The Distinct Contributions of Educational Research and Researchers International Conference, Dublin, Ireland, 1-15.

https://pure.au.dk/portal/en/publications/contextfree-pragmatism-indanish-campus-architecture(d6ba667e-9095-4513-8c3b-

5bc673b2a0ff)/export.html

Lægring, K. (2017). Bjarke Ingels and The Return of Representation: A Challenge to The Post-critical. Architecture and Culture, 5(2), 315-340. https://doi.org/10.1080/20507828.2017.1328206

Levi-Strauss, C. (2000). Yaban Düşünce (La Pensée Sauvage). YKY.

Møller, A. (2013). Yes Is More: The BIG Philosophy. ArchDaily. https://www.archdaily.com/366660/yes-is-more-the-big-philosophy

Pallasmaa, J. (2016). Tenin Gözleri. YEM.

Pastor, C. E. (2012). La Arquitectura Diagramática Y Sostenible De BIG (BIG's Diagrammatic and Sustainable Architecture). Revista de Expresión Gráfica Arquitectónica, 20, 184-193. https://doi.org/10.4995/ega.2012.1440

Sağdıç, Z. (2016). The 21st Century Architecture: Searching of The Concept. Megaron/Yıldız Technical University, Faculty of Architecture EJournal, 11(1), 179-186. https://doi.org/10.5505/megaron.2016.93064

Tschumi, B., \& Cheng, I. (2003). The State of Architecture at the Beginning of the 21st Century. Monacelli.

Url-1: Hedonistik Sürdürülebilirlik, [Hedonistic Sustainability] XXI. Retrieved from https://xxi.com.tr/i/hedonistik-surdurulebilirlik

Url-2: Geçicinin Gerekliliği, [Necessity of the Temporary] XXI. Retrieved from https://xxi.com.tr/i/gecicinin-gerekliligi 
Url-3: Lego House Images: Retrieved from

https://www.archdaily.com/880900/lego-house-big

Url-4: Lego Tower Images: Retrieved from https://big.dk/\#projectslego

Url-5: Lego Tower Images: Retrieved from

http://files.archinect.com/uploads/ai/aiu_LegoHousingBIG.jpg

Url-6: Lego Tower Images: Retrieved from

https://www.designboom.com/architecture/big-architects-yes-ismore-exhibition/

Url-7: Mountain Dwelling Images: Retrieved from https://big.dk/\#projects-mtn

Url-8: Mountain Dwelling Images: Retrieved from https://www.archdaily.com/15022/mountain-dwellings-big

Url-9: Mountain Dwelling Images: Retrieved from https://www.google.com/maps/place/Mountain+Dwellings/@55.6350 $579,12.5828625,14 \mathrm{z} /$ data $=! 4 \mathrm{~m} 13 ! 1 \mathrm{~m} 7 ! 3 \mathrm{~m} 6 ! 1 \mathrm{~s} 0 \times 465254$ baa9662891:0 x812d83688f74c488!2sMountain+Dwellings, $+2300+K \%$ C3\%B8benhav n,+Danimarka!3b1!8m2!3d55.63525!4d12.582917!3m4!1s0x0:0x1533b 77107bf0ea3!8m2!3d55.6350579!4d12.5828624

Url-10: King Street West Images: Retrieved from https://big.dk/\#projects-king

Url-11: King Street West Images: Retrieved from https://urbantoronto.ca/news/2016/04/bjarke-ingelsgroups-kingstreet-vision-detailed-consultation

Url-12: King Street West Images: Retrieved from https://urbantoronto.ca/news/2017/05/update-bigs-king-west-20impresses-public-planning-less

Url-13: King Street West Images: Retrieved from http://kingtoronto.com/floorplansUrl-12

Url-14: King Street West Images: Retrieved from https://urbantoronto.ca/news/2020/10/excavation-setting-stage-riseking-torontos-mountains

Url-15: 79 \& Park Images: Retrieved from https://www.archdaily.com/905534/79-and-park-big

Url-16: 79 \& Park Images: Retrieved from https://big.dk/\#projects-st7

\section{Resume}

Ayșenur Dağ Gürcan is a PhD student in Architecture at Gazi University, Ankara, Turkey. She was graduated from Ballkesir University, Department of Architecture in 2014. She received her MSc degree in Architecture from KTO Karatay University, in 2017. She is currently working as an academic lecturer at the Department of Architecture at KTO Karatay University. Her research interests include architectural history and theory, contemporary architecture, Turkish Islamic architecture, and vernacular architecture.

H. Ercan Gürcan is an MSc student in Architecture at Konya Technical University, Turkey. He got his B.Arch. degree in Department of Architecture at Erciyes University in 2014. He is currently working as an architect. 